\title{
Background of a History: Cappadocia Houses
}

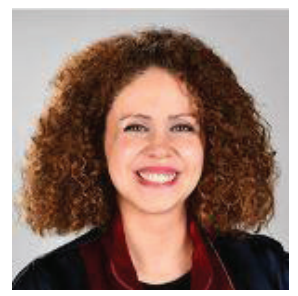

Assoc. Prof. Dr. Arzu ERÇETIN

İstanbul Kultur University

Department of Interior Architecture \&Environmental Design

a.eceoglu@iku.edu.tr

Abstract: Cappadocia has hosted many cultures with its history. There are works of art in the region belonging to the pre-Christian period, the period when Christianity arose and developed, and the periods of Islam. The architectural structure of the region is shaped by the features offered by the geographical structure. It has created the identity of the region with its striking architecture on the surface and mysterious underground cities underground. Having a heritage of a large number of different structure types of buildings, province of Nevsehir, and especially Cappadocia region in Turkey with structures and groups of structures is very important for the whole world. 60 million years ago; the region formed by the eroding of the soft layers formed with the lava and ashes erupted by Erciyes, Hasandağ $\mathrm{l}$ and Güllüdağ, by rain and wind for millions of years, has hosted many beliefs and civilizations with its historical and architectural texture dating back to the Paleolithic period. The main purpose of the paper is to discuss the architectural works of the Cappadocia region, which provides integrity with the geographical location, in terms of history, the concept of space and the organization of the space and to reveal a research.

Keywords: Cappadocia, Structure, Space organization, History, Geographical space

\section{Bir Tarih'in Arka Planı: Kapadokya Evleri}

Öz: Kapadokya, tarihi ile birçok medeniyete ev sahipliği yapmıştır. Hıristiyanlık öncesi dönemi, Hıristiyanlığın ortaya çıktığl ve geliştiği dönem ve Islamiyet dönemlerine ait bölgede birçok eser bulunmaktadır. Bölgenin mimari yapısı coğrafi yapının sunmuş olduğu özelliklerle şekillenmiştir. Yerüstündeki göz alıcı mimarisi ve yeraltındaki gizemli yeraltı şehirleri ile bölgenin kimliğini oluşturmuştur. Mimari açıdan çok sayıda ve birbirinden farklı yapı türleri mirasına sahip olan Nevşehir ili özellikle Kapadokya bölgesi yapı ve yapı grupları ile Türkiye ve tüm dünya açısından önem teşkil etmektedir. 60 milyon yıl önce; Erciyes, Hasandă̆ ve Güllüdăg’'n püskürttüğ̈̈ lav ve küllerin oluşturduğu yumuşak tabakaların milyonlarca yıl boyunca yağmur ve rüzgâr tarafindan aşındırllmasıyla oluşan bölge, Paleolitik döneme uzanan tarihi ve mimari dokusu ile birçok inanç ve medeniyete ev sahipliği yapmıştır. Bildirinin asıl amacı coğrafi mekân ile bütünlük să̆layan kapadokya bölgesinin mimari eserlerini

Anahtar Kelimeler: Kapadokya, Yapı, Mekân organizasyonu, Tarih, Coğrafi mekân

Doi Num : 10.17932/IAU.ARCH.2015.017/arch_v05i2003 


\section{INTRODUCTION}

Cappadocia region is one of the oldest places used as a settlement area in the historical process. Cappadocia is one of the most important centers of the Hittite Kingdom. Besides being an important settlement area for the Hittites, it also covers the center where the "Assyrian" trade colonies, an important milestone in Anatolian civilization, were established. In addition to being the place where the trade of Mesopotamia moved to Anatolia, Cappadocia is also known as the place that helped Assyrians to bring the indigenous writing of Mesopotamia to here, and it also became one of the important centers of the Silk Road in the Middle Ages and later in the Ottoman period [1]. It is an important belief center for Christians around the world in terms of being the hiding place of Christians who escaped from the persecution of the Roman Empire in the early Christian period [2]. As can be understood from the originality of the churches built in the region, it is understood that there is a cult center for the wall frescoes. For these reasons, the natural forms that came from the geographic structure of Cappadocia in the region are the residential areas preferred by people especially for the purposes of hiding and defense.

The Nevşehir-Ürgüp area, which constitutes an important part of the Cappadocia region, therefore has a structure suitable for human life and housing construction. Today, the region used as a residential area is used with different space functions while preserving its historical textures.



Figure 1. Nevşehir settlement plan

https://www.kapadokyarehberliturlar.com/harita-uzeri-bilgiler/Erisim Tarihi 02.03.2020 


\section{AN OVERVIEW OF URGUP ARCHITECTURE}

There are marks showing that human settlements have been found in Cappadocia region since the very ancient times. The local people, who created the places by digging the rocks in form of masses, not only led to erosion that wore the environment as a result of these excavations but also helped to enrich the geological structure of the environment. Communities have been in close contact with nature and have created different types of settlements depending on changing physical and geographical conditions.

"The relationship between the environment and the form of human settlements becomes more open and observable as physical shapes become more difficult in Cappadocia, which is the interesting aspect of Cappadocia. The variety of settlements shows that geographical conditions have more impact on settlements as they become more and more harder besides getting more difficult. While the dwellings are well-defined and have independent architectural characteristics in the smooth plateaus or in low slope areas, on the lands that emerged as a result of volcanic formations, they had to get out of the normal housing types with the influence of nature and as opposed to the ongoing building process, they obtained rock forms."

Cappadocia region has a rich texture by showing different social, cultural, political and spatial features in the historical process. When the general architectural character of the Cappadocia Region is examined, Ürgüp dwelling architecture and its characteristics draw attention. When the historical process is taken into consideration, it can be seen that the Cappadocia Region has spread to wide geography. Within the scope of this study, the dwelling architecture of Ürgüp, which is one of the important settlements within the borders of Cappadocia, and the structural and spatial characteristics of Ürgüp dwellings will be examined. It is possible to say that the social, political, cultural and climatic effects of the region where Ürgüp residences have different characteristics are reflected in the dwelling architecture (Figure 2). Ürgüp houses have been examined under three headings in the researches. These are;

- Carved rock-dwelling

- $\quad$ Carved rock-dwelling + Masonry dwelling

- Masonry dwelling

First of all, the building materials used are the same. There may be only minor conditions that depend on the environment. Especially the stones are in this state. The colors of the stones, the degree of hardness may differ depending on the region. Typical poplar and tar tree in wood flooring; The window cabinet door door leaves, floor and ceiling coverings also open pine tree.

It is the construction technique in a common matter. The stone building system and technique used in the region are also applied in Uçhisar. Some changes are only observed in stone decorations. This change and diversity is due to the style and style of the masters working in the region. The settlement, which was formed as a rock carving (rock dam), was formed in the form of horizontal layers and vertical connections within this main mass, which covers an area of 95 meters and covers an area of $9.000 \mathrm{~m}^{2}$. It was used for protection purposes and equipped accordingly, and this main mass was used up to 15 centuries [12].

Later, rock-carved spaces started to spread especially to the slopes overlooking Güvercinlik Valley on the south-east side of the area. It spread to the Fairy Chimneys in the northwest. The southern slopes, on the other hand, have chosen the location of the settlement in terms of seeing the natural landscape and the suitability of the east-south-east slopes for micro-climatic reasons. In the late 16 th and 17 th centuries, places were built using cut stones obtained from the tuff structure of the region with arches and vaults, and the original city texture and housing types that we are trying to protect. 
The streets were formed in parallel to the slopes and the houses were created by carving the elevation differences between these streets. (See Analysis Sheet 1: Texture-Structure-Street Relationship) The houses are usually surrounded by walls from the lower level. The courtyard is entered through a wide door, onestorey and two-storey spaces are placed on the rock-carved spaces around the courtyard in one direction. The 2 nd floors are always structured so as not to cover the view of the building behind it. The first floor was used as the terrace of the other. These spaces are accessed by stone stairs leading from behind.
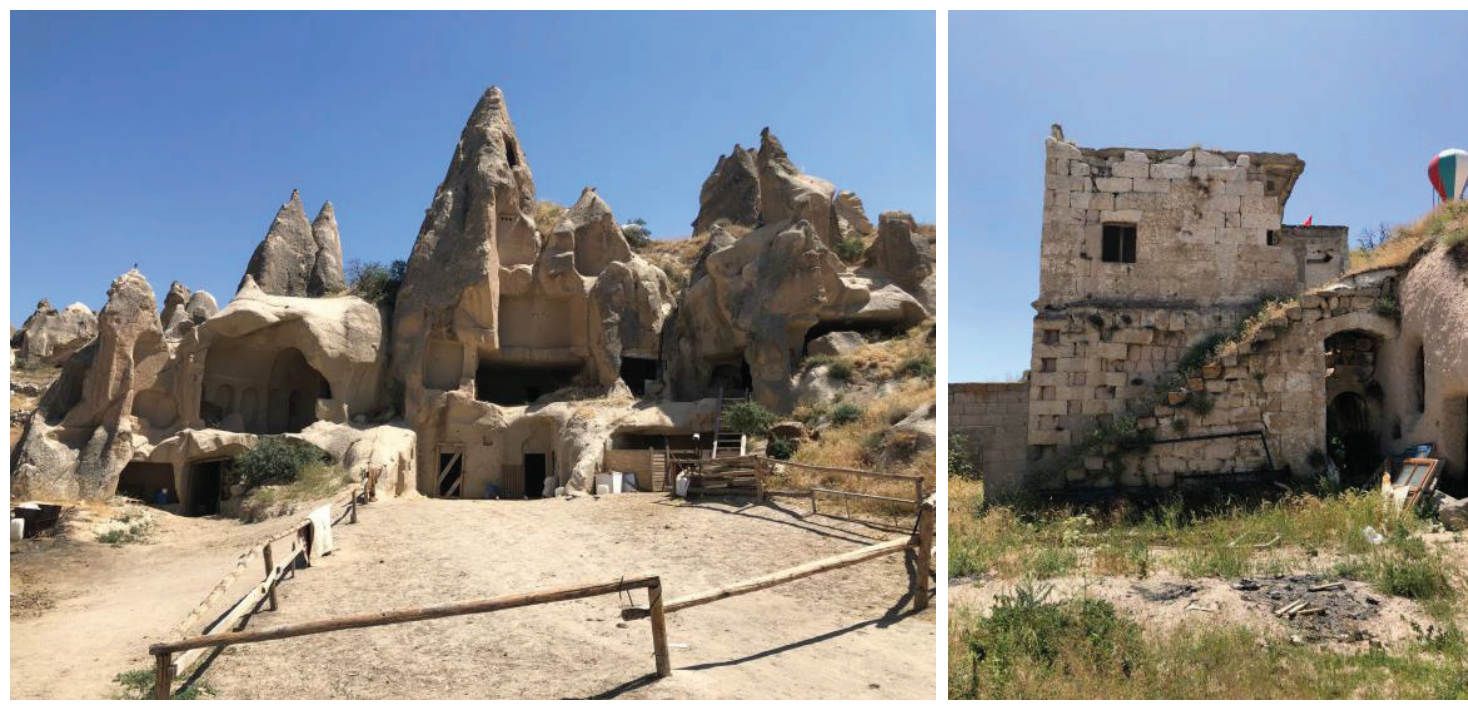

Figure 2. Rock carved housing example, Masonry housing example (Author photo archive 2019/2020)

The structures and forms of the villages in the valleys of Cappadocia are determined by the geological features of the place that the villagers chose to settle. For this reason, it is seen that the villages are sometimes located underground, sometimes on the rocky faces of mountain valleys or along the slopes, and sometimes on individual rocks one by one. "We see the similar effects that people made when they cut holes in the rocks, in forces that erode nature. Therefore, places that look like multi-storey space arrangements usually do not prove to be a multi-storey settlement pattern in the area. The carving process was abandoned at the upper levels with the wearing of the valley floors and went down to the lower levels by following the valley floor. On the other hand, to reach the valley floors and connect different levels, stairs were carved, rope stairs were built and paths were opened on the slopes of the rocks" (M.G. Kalayc1). Also, we can see Churches (Figure 3) that have been carved into tufa rocks since IV. Century. Even though the modernity and richness of these churches in those periods, they are in ruins today, they still maintain their entire splendor with their engravings still on their walls. Although these churches were affected by wearing, they were more resistant to earthquakes than structures built in the same period. The underground cities built by the public in order to protect themselves from the attacks were also achieved by the engraving method that the geological structure allowed. Examples of these underground cities are three-storey underground city in Kaymaklı and seven-storey underground city in Derinkuyu. 

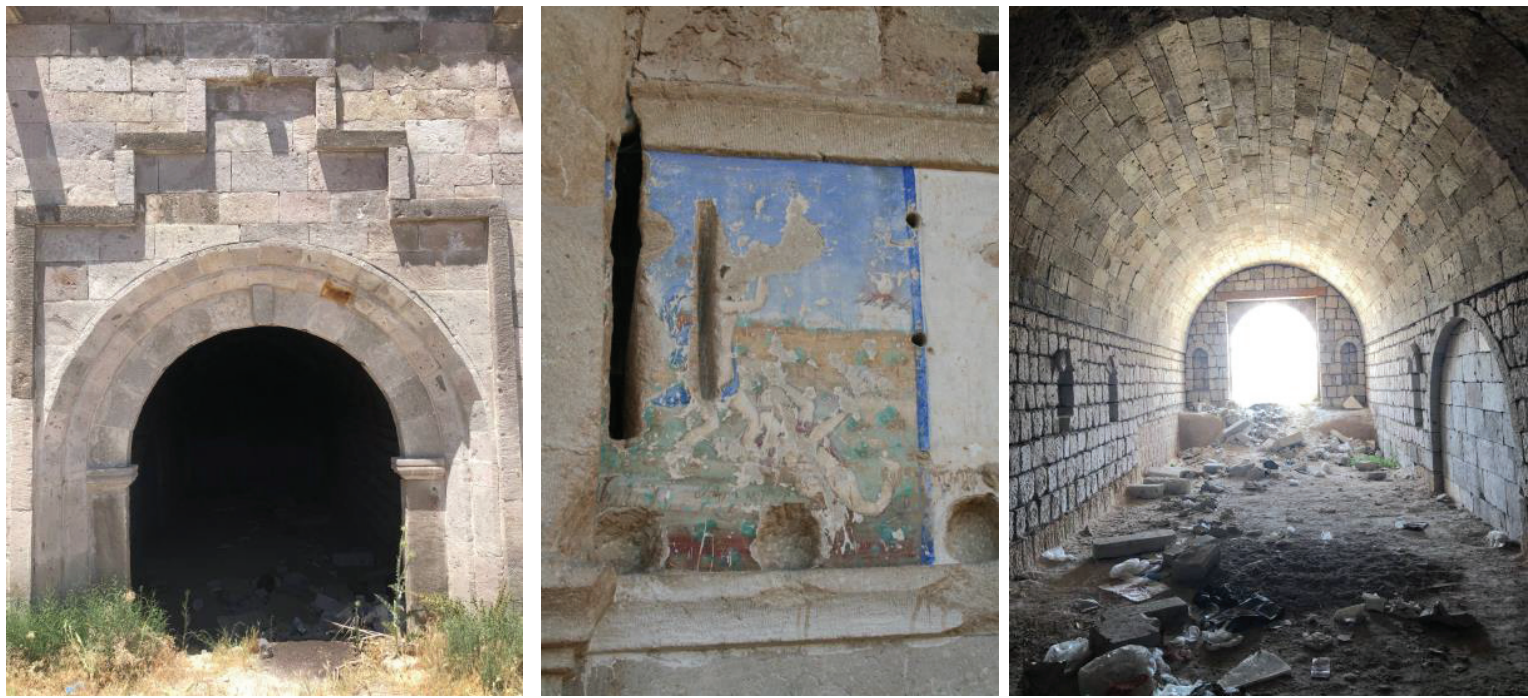

Figure 3. Church entrance and wall processing example (Author photo archive 2019/2020)

In the region, which has a completely organic texture, the architectural structure was developed depending on the topography. Old houses built with rock carved spaces and stone materials and masonry technique give an appearance as if they overcame each other along the slopes. These settlements, which have an extremely adjacent and dense texture, also show a harmonious integrity with the natural environment. Some of the structures carved into the rock in Cappadocia were built for security purposes and some were built for seclusion purposes. There are no traces of settlements except for the small holes for doors, windows or ventilation. In Ürgüp and in its surroundings; as a result of natural structure, environmental conditions, wars and occupations, a very original residential architecture has emerged. Stone houses in Cappadocia are residential, whether shaped by human intervention or subject to no treatment.

In Anatolia, privacy has an important place in traditional houses, examples of which have survived to the present day. For this reason, in houses with a yard, the walls of the courtyard are high and more closed planning has been used in the houses without a courtyard on the ground floor level. On the contrary, in Ürgüp houses, there is a structuring more intertwined with the street. The outer walls of the houses shape the street. Houses are usually entered directly from the street. In the houses with courtyards, the courtyard is usually at the back of the house. There is almost no example with large courtyards. In the existing small courtyards, generally, nothing is planted. The floor of the courtyards is stone paving or compacted earth lining. These spaces are general circulation areas. Places such as barn, hayloft, warehouse and tandoori house open onto the courtyard. The stairs that go upstairs are also located here. In some houses located in areas with high land slope, the ground floor can be entered from one street, while the upper floor can be entered from the other upper street. If you enter the courtyard from the street first and then to the house, the connection between the courtyard and the street in this type of residence is established through the "frontentrance door" (opening to the environment - a common one used by everyone). The toilet is located adjacent to the sentence door, on the right or left. Another remarkable feature in traditional Ürgüp residences is that the courtyards of the houses are usually located at the back of the building. The reason for this is to leave space for the courtyard in between while adding masonry houses to the rock-carved houses that were built in the past. 
According to Binan (1994), they are distinguished from other types of dwelling by being generally symmetrical in the plan schemes of masonry houses. Towards the end of the 19th century, rich plans and front layouts were adapted to the architecture of the region. In the Cappadocia region, Mustafapaşa (Sinasos) and Güzelyurt (Gelveri) residences are the residential settlements that have survived until today. In addition, these are the dwellings built by people that were in a close relationship with other cities of Anatolia in the region, built at one time based on the principle of universal planning. We see that these examples are the dwellings with interior and middle courtyard plan types and also have local characteristics and they started to appear in the other big cities as well as from the beginning of 19th century.

According to the structure-open space relationship, we can divide the Ürgüp residences into two with and without a courtyard [3].

\subsection{Dwellings Without a Yard}

In this type of residence, the entrance to the building is directly from the street. The outer walls of the building shape the street. There is a life more intertwined with the street. Mostly, the buildings that lie back on the rocks are of this type.

\subsection{Dwellings With Courtyard}

We can divide the dwellings with courtyards into four groups: courtyards on four sides, courtyards on three sides, courtyards on both sides and courtyards on one side. Dwellings with one-side or two-side courtyards are more common in Ürgüp.

\subsection{Dwellings With Courtyards On Four Sides}

In this type of dwelling, you can enter the courtyard and then the building from the street. The courtyard provides a link between the building and the street. In some of these types of dwellings, the courtyard is large enough to accommodate areas to be planted and have trees. In the others, it is only enough to provide transition to the volumes in the courtyard.

\subsection{Dwellings with courtyards on three sides}

In this type of dwelling, the building is either a border to the street, and there are courtyards on the other three sides, or the back of the building lie on the rock, and a courtyard on the front and on the other sides. There is a door to enter the courtyard from both the street and the building [4]. There are service areas such as warehouse, barn, toilet, tandoori house in the courtyard.

\subsection{Dwellings with courtyards on both sides}

This type of dwelling is either built in an adjacent order, with a courtyard in front and behind it, or the building is on the street corner and the courtyard on two other sides.

\subsection{Dwellings with courtyards on one side}

This type of dwellings is built in an adjacent order, bordering the street. Their courtyards are behind the dwelling, between the dwelling and the rock. First of all, you go to the lower floor, and then to the courtyard with another door. There are also examples of the dwelling that first you go to the courtyard before the street and then to the dwelling of which back lie on the rock. 


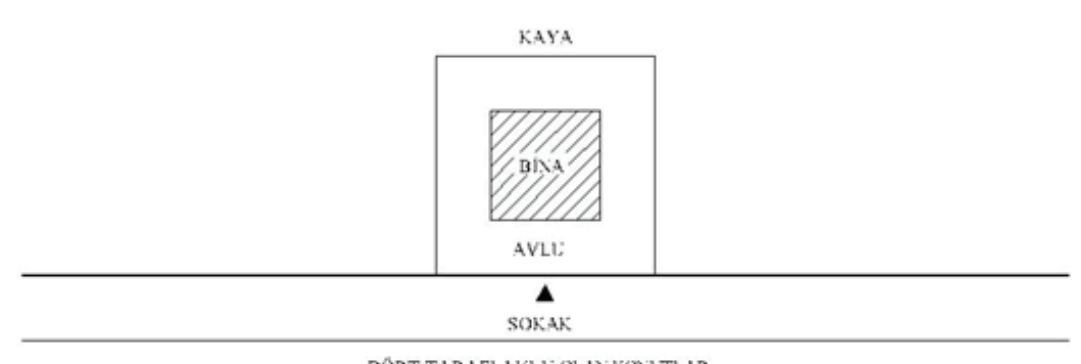

DORT TARAFI AVLL: OLAXKONI,TLAR
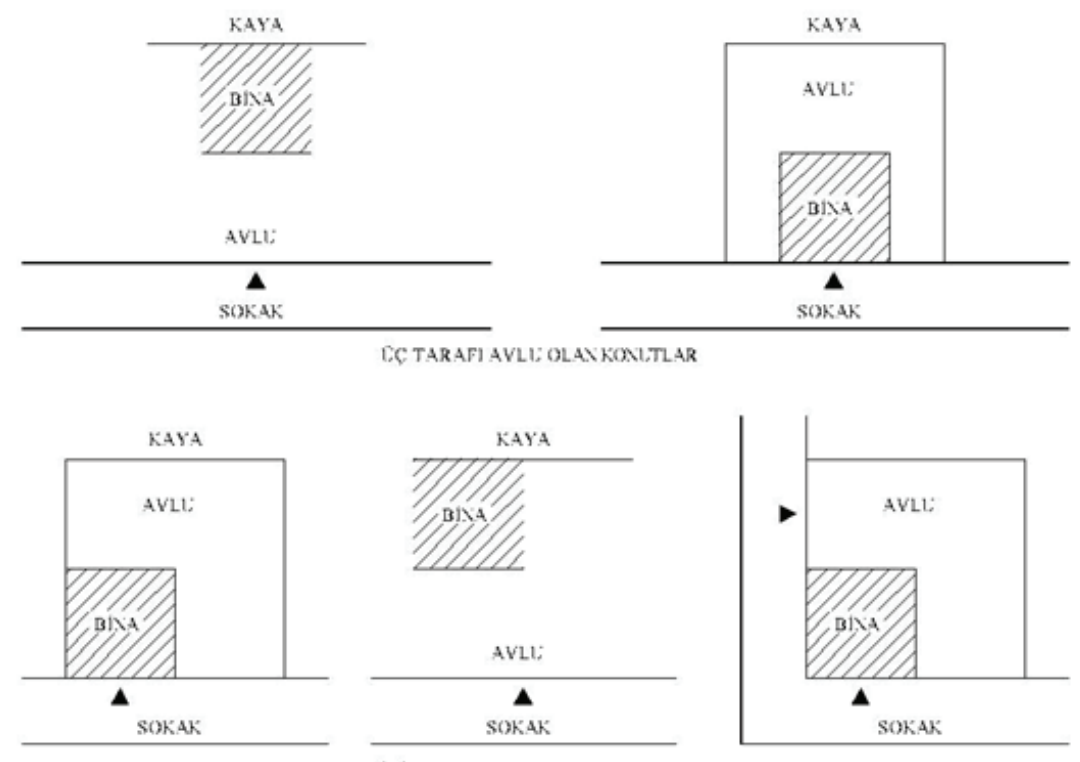

IKI TARAFI AVLL: OLANKONLTLAR
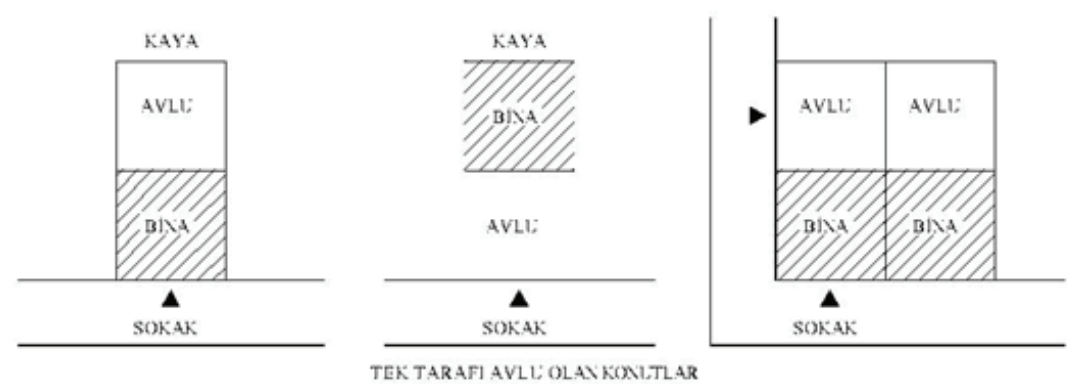

Figure 4. Courtyard-Street relationship (taken from M. G. Kalaycı, Traditional Ürgüp Houses and Dereler Neighborhood Conservation Development Suggestion Master Thesis).

\section{PLAN FEATURES OF CAPPADOCIA HOUSES}

In Ürgüp houses, which are divided into two groups as carving and semi-carving-half-mansonry according to their construction systems, the residences consist of three sections: dwelling, living and barn. In the living area, there are local tandoori, arbour and recording rooms [5]. Living section is the walled section with a toilet in one corner, which is used to do their works in front of the house. There are animal shelters and hayloft in the barn section (Figure 5). 

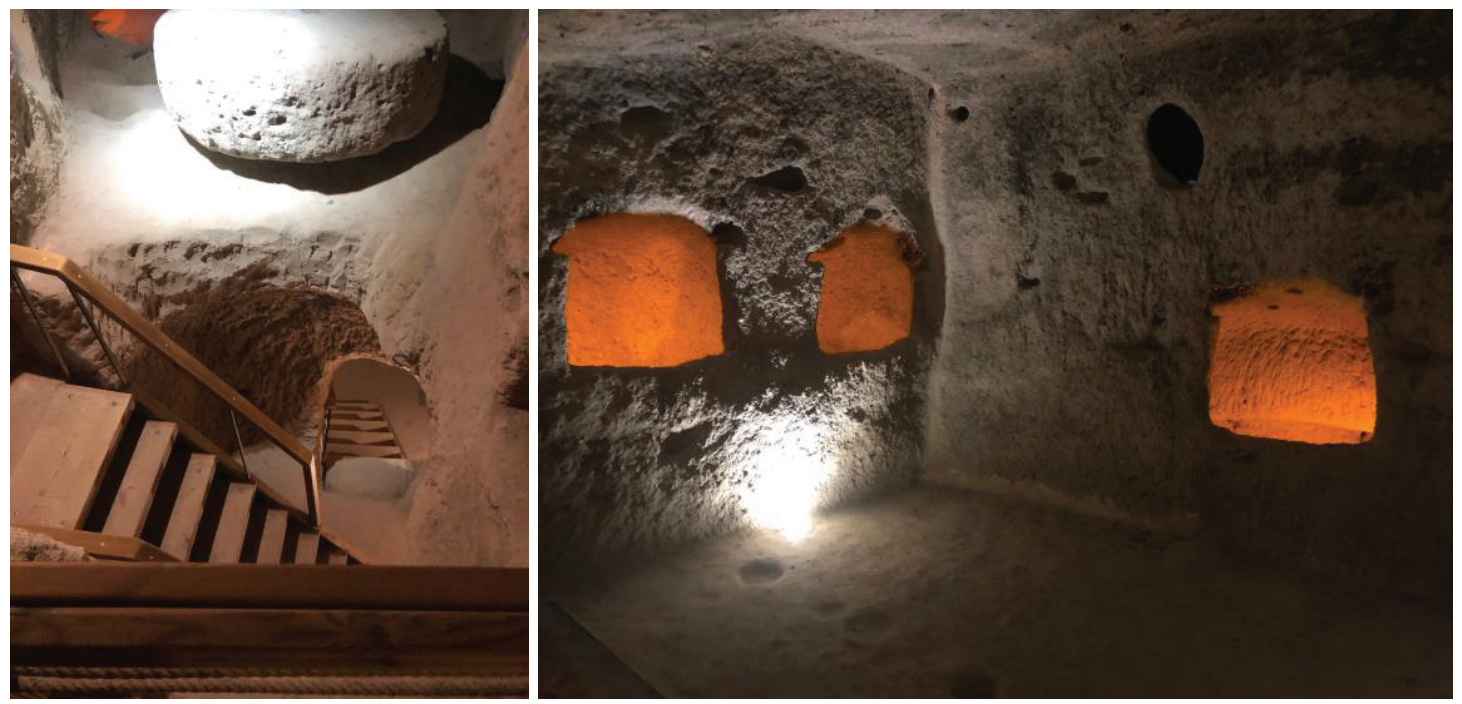

Figure 5. Underground city interior photos (Author photo archive 2019/2020)

As a result, a traditional urban fabric, which is compatible with the topography, overlooking the landscape and closed to the north wind in general, was formed. The fact that new ones were added to the carved spaces behind the courtyards put the use of the land in an intricate and complex situation. Often these places have entered the streets or houses (on the lower levels) in the upper level. This situation has now put property rights into an insurmountable situation. It caused collapses due to occasional overlaps or external wear of the gully and caused deterioration in their superstructures. These constructions have developed from time to time with fairy chimneys and even overlapping them, fairy chimneys have been used as living and storage areas.

The skillful understanding of static and aesthetics of the stone masters in the region has developed very well and has created very good solutions. In addition to these solutions, the interior and exterior interiors and decoration of the building elements also feature. Although not many, unique stone carving decorations on the facades of some houses attract attention. Although not very precise, the plan scheme is usually 2 or 3 types. The fact that the land is steep and the masses are arranged along the length of the slope prevented the formation of a very standard plan scheme. Generally, they are 1 or 2-storey spaces formed on the courtyard and the surrounding rock-carved spaces. In general, the low single space constitutes the terrace of the 2 nd floor.

In Cappadocia house, we see a plan type that covers each other, that is, it is formed by arranging the rooms around a sofa. In rooms that are generally square type, the room is in the form of a living unit with little variation in shape, size, and qualities. The rooms are built in proportional modules. These modules are formed as 4m. x 4m., 3m.x 3m.The rooms in Ürgüp houses are similar to Anatolian architecture in terms of structure and show the Safranbolu house type.

Many spatial features are similar, from sitting and resting actions on the cushions placed on the ridges on the flooring in the living spaces, to niche-shaped cabinets formed on the walls. In the area, in traditional dwellings mostly the upper floors were used as living area. On the ground floor, winter room, service and warehouse etc. areas were located [11]. The sofa, which we can call the space between the rooms, is variable with every single feature. In Ürgüp houses, sofas were determinant for the plan types of traditional dwellings [6]. Such that, the number of rooms was determined according to the condition of the sofa, in 
the structures located on the slope areas where the slope is high, the sofas would merge with rock carvings and extend into the rocks.

The cooking or dining place called tandir, the barn and the toilet are located on the ground floor level and around the courtyard. On the upper floor, there is a vaulted room or an iwan, reached by a ladder, a room was built on both sides of the section with open-arched section called the divanhane. Generally, there are 2 rectangular windows on the facades facing the courtyard or the street. Window jambs are composed of lintels and windowsills of hard stone (black stone) and are secured with iron bars. The joinery is wooden and has wings. Room doors are wooden. It is generally close to the back wall, which is reached by a ladder. There are cabinet niches or stove between the two sides on the side walls where the arches sit. The floor covering is stone and some buildings are covered with wood. The roof cover is generally made of stone arches and is toned and the roof is made impermeable to water by compressing the clay soil in the area. In some buildings, both the 1 st floor pavement and the top floor cover are lined with stones in a short direction on the stone walls in a short direction, and the trees are covered with wicker or dry branch leaves, and the top is filled with clay soils and made it impermeable to water. The water currents of the flat roof were thrown out of the building thanks to the buns.

\subsection{Types With Internal Sofa}

It came into focus in the 18th century, but it became widespread in the 19th century [10]. The crowding of the cities, reducing the land and its rise in value required more inward-oriented and tight planning. The desire to live more comfortably, to avoid dust, cold, and the need to use the sofa area all the time are among the social reasons for choosing this type. This ordered plan included more rooms, the walls were decreased in number and it gave an opportunity to reduce the cost thanks to the rooms next to each other. According to another point of view, the type of middle sofa plan is a house type that has been used since Central Asia, and it was applied in the types of buildings such as madrasahs, mosques and mansions in Anatolian Turkish architecture, and it has found a re-application area in big cities, in the houses of administrators. Symmetry in one direction can be seen in the internal sofa type.

An arched, vaulted architectural structure dominates the spaces. The material of both the courtyard and the house doors are wooden. The upper part of the arched doors is decorated with stylized ivy or rosette motifs. The consoles on stopes of the floors of the houses are sometimes filled with single and sometimes 2-3 rows of rosettes, stars, fan, pinwheel and stylized plant motifs. In addition, this type of woodworking can also be found on the ceilings [7]. The windows of the houses are double or triple and their surroundings are mostly decorated with stylized plant motifs. The windows are of two types, "winged" and "guillotine" style. There are many rooms, kitchens, warehouses, tandoori, cellars, wineries in the houses. In the niches in the guest rooms, there are adornments painted on plaster. Stone fireplaces, stone stairs, decorative niches, cedars, local carpets, pots, object are indispensable elements in decoration (Figure 6). 

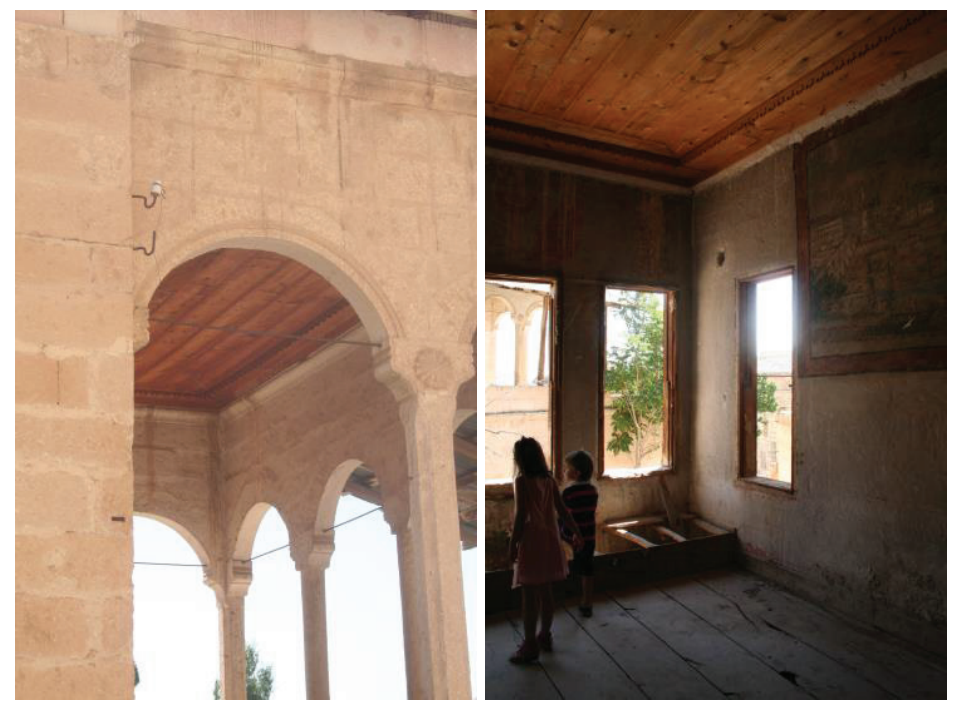

Figure 6. Elements in decoration (Author photo archive 2018/2019)

\subsection{Type With Outer Sofa}

The type of house known as Divanhaneli houses with its local name is called the type with outer sofa. The outer sofa plan types, which usually have a courtyard, are read in the plan in different ways. Divanhanes, some of which are open on three sides, their top is covered and easily readable from the front, can be reached by stone stairs from the garden [8]. These Divanhanes are surrounded by a guardrail in height of around $80 \mathrm{~cm}$. We see that this guardrail is sometimes concrete, and sometimes iron. There are three or four rows, generally rounded, stone and arched columns among the guardrails of the divanhanes, which are open on both sides.

\subsection{Plan Type Without a Sofa}

This type of dwellings is designed in smaller sizes. The downstairs, which is entered through a stone road from the street, has service areas such as a toilet, kitchen and barn, and there is a staircase leading up to the upper floor rooms [9]. In the plan type without a sofa, there are generally two rooms and a small sofa on the upper floor or more rooms that are placed irregularly (Figure 7). This plan type is also found in semicarved - half-masonry traditional dwellings. However, in these types of dwellings, the transitions between rooms are provided from the courtyard [8]. 

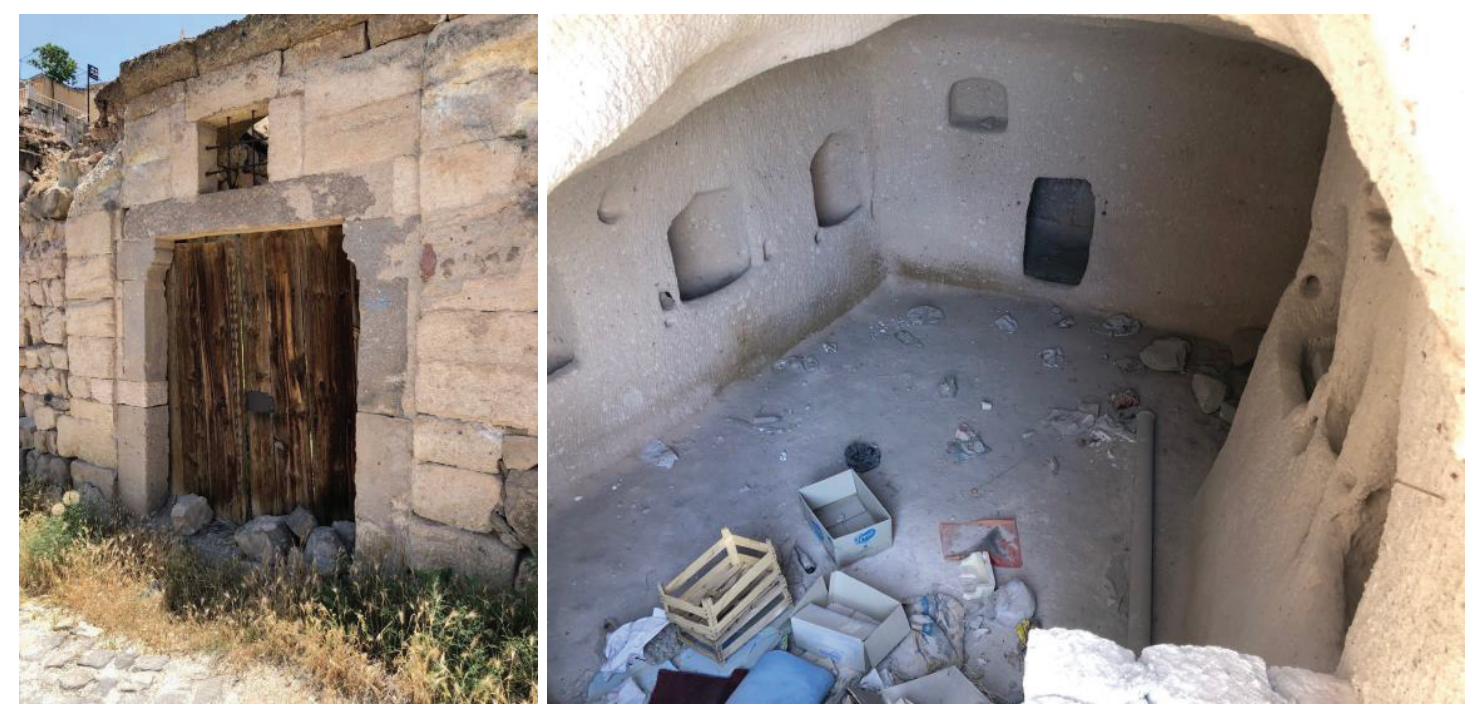

Figure 7. Two rooms and a small sofa on the upper floor or more rooms (Author photo archive 2019/2020)

\section{CONCLUSION}

Having a geological structure with a volcanic origin, Ürgüp was established in an area where there are frequent and typical examples of interesting natural formations defined as fairy chimney created by rain and wind erosion. The fairy chimneys rising between the crevices formed by the erosion of the rainwater flowing from the valley slopes and then by the erosion of winds have created a very interesting landscape image unique to this region. Today, Ürgüp in Cappadocia is regarded as Turkey's one of the most important regions in terms of tourism activities. The historical, topographic and architectural features of the region are among the remarkable elements. Especially the integrity of the topographic structure with the architectural structure is one of the fascinating features.

Today, on the contrary to the houses used while preserving their originality, Ürgüp houses appear with different functions. Although these functions have been evaluated especially in terms of tourism, the renovated buildings are renewed by making all the controls and sticking to their originality. Many of them maintain their lives as hotel, hostel, and restaurant-style touristic structures as a result of this renewal process.

The region, which has hosted many civilizations throughout the history, is still trying to preserve its origin. We can see that besides the fact that structures that provide compatibility with the geographical location are formed in accordance with the usage plan as well as the "U Type" - "L Type" - plan scheme. The Ürgüp houses, which are spatially dominated by the natural environment and open for recreation in the urban environment, also reveal their characteristic identity. When the plan scheme is examined, all the figural, dimensional, proportional and textural features of the spaces can be viewed as read-only. 


\section{REFERENCES}

[1] Akgüç, A., Atuk, N., (1987). Kültür ve Turizm Bakanlı̆̆ Taşınmaz Kültür ve Tabiat Varlıkları Yüksek Kurulu 3447, Ankara, 1-14.

[2] Cimok, F., (1987). Cappodocia, A Turizm Yayıları, İstanbul, 5-21.

[3] Çelik, M., (1989). Bir Grup Geleneksel Avanos Evinin Sağlamlaştırılması ve Turizm Amaçlı Kullanım Projesi, Yüksek Lisans Tezi, Hacettepe Üniversitesi Sosyal Bilimler Enstitüsü, Ankara, 27-32.

[4] Eravşar, O., (1996). Kapadokya'da Yerleşim Alanları ve Sorunları, Kapadokya Vakfi Yayınları, Nevşehir, 9-88.

[5] Esmer, M.A., (1992). Avanos’un Eski Türk Evleri, Kültür Bakanlı̆̆ı Yayınlarl, Ankara, 13-58.

[6] Görmez, K., (2002). Kapadokya Mevcut Durum Raporu, Kültür ve Turizm Bakanlığı Yayınları, Ankara, 1-197.

[7] Kaya, M., (1994). Geçmişten Günümüze Ürgüp, Mozaik Dizgi, Ankara, 8-89.

[8] Kuban, D. (1982). Türk ve İslâm sanatı üzerine denemeler (Vol. 1). Arkeoloji ve Sanat Yayınları.

[9] Kuban, D. (1998). İstanbul Yazılar1, Yap1 Endüstri Merkezi.

[10] Özkan, S., Önür, S., (1974). Kalın Duvarlar Örüntüsü ve Kapadokya’da Mimarlık, Mimarlık, 5.

[11] Tekeli , İ., (1993). İcabında Plan... İstanbul Dergisi, Tarih Vakfi Yayınları, sayı:4, ss:26-38

[12] Tunçer, M. (2012). Nevşehir-Uçhisar Belediyesi Koruma Planlaması Çalışmaları, mehmeturbanplanning.blogspot.com/2012/03/nevsehir-uchisar-belediyesi-koruma_18.html, last accessed on 16 April 2020

\footnotetext{
ARZU ERÇETiN, Assoc. Prof. Dr.

She completed her undergraduate education in 2005 at TC Haliç University, Department of Interior Architecture, her master's degree in 2007 at Istanbul Kültür University, Institute of Science and Technology, department of Interior Architecture and in 2010, she completed her proficiency in arts with the title of Dr. in MSGSU Institute of Science and Technology, Department of Interior Architecture. She continues her work on space organization, color, design and interdisciplinary studies. She also has design patents, national and international congress presentations, articles, book and book chapters and competition projects. Besides her academic identity, she has a number of applied interior design projects and is a member of the Board of Directors of the Istanbul Chamber of Interior Architects. Erçetin has been working at Istanbul Kültür University since 2007.
} 